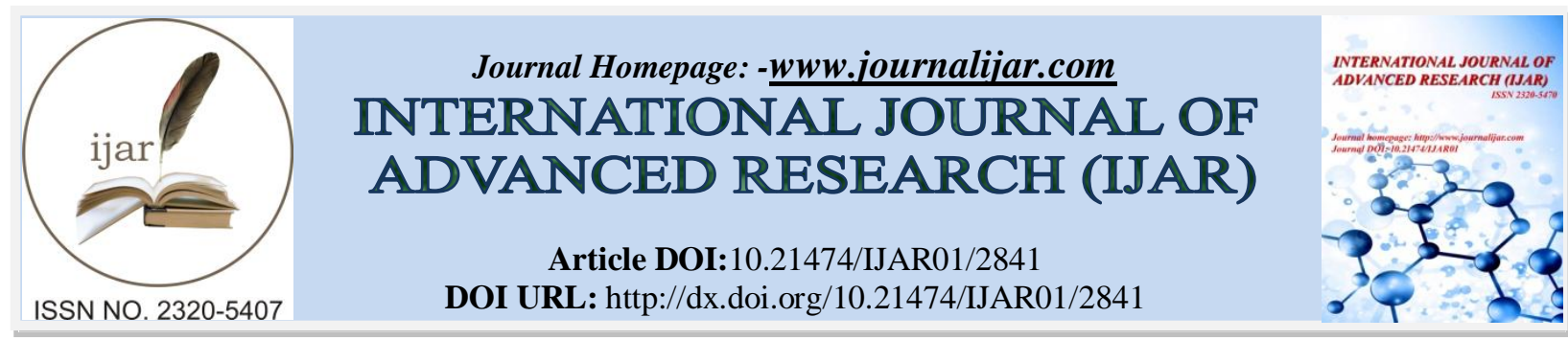

RESEARCH ARTICLE

\title{
A DYNAMIC PANEL DATA MODEL FOR ANALYZINGTHE RELATIONSHIP BETWEEN MILITARY EXPENDITURE AND ECONOMIC GROWTH AND POPULATION IN 54 LESS DEVELOPED COUNTRIES.
}

\section{Masoud Ali Khalid.}

College of Financial \& Administration-Department of Accounting \& IT, Cihan University/ Sulaiymani, Kurdistan Region Government/Iraq.

\section{Manuscript Info}

\section{Manuscript History}

Received: 18 November 2016

Final Accepted: 19 December 2016

Published: January 2017

\section{Key words:-}

Military expenditure; Economic growth; Developing countries; and SGMM Estimates.

\begin{abstract}
Several alarming and largely ignored trends in the structure and size and of military spending of less developed countries (LDCs) have appeared during the past five decades. This study analyses the defensegrowth relationship for 54 developing economies by using crosssection data such as random effect, fixed effect and system GMM model. The empirical results, bearing in mind the possible inaccuracies of the data set and given the chosen model, suggest that defence spending has a positive relationship with both the rate of economic growth and population in the sample countries.
\end{abstract}

Copy Right, IJAR, 2016,. All rights reserved.

\section{Introduction:-}

Since Benoit's (1973) seminal work, the relationship between military spending and economic growth in developing countries has been the subject of widespread empirical study. Theoretically, however, there is no clear-cut prediction of the relationship between defense spending and economic growth. On the one hand, military expenditure may retard economic growth through what is generally referred to as an investment "crowding-out" effect, or a displacement of an equal amount of civilian resource use. Otherwise, military expenditure may also stimulate economic growth through Keynesian-type aggregate demand impacts. An increase in demand generated by higher military expenditure leads to increased utilization of capital stock, higher employment and profits, and, therefore, higher investment, which further generates short-run multiplier effects. In addition, economic growth stimulates spin-off impacts such as the creation of socioeconomic structures conducive to growth (Deger, 1986).

Even though defense spending would affect economic growth through these mechanisms, Joerding (1986) mentioned that economic growth maybe causally prior to military spending. For instance, a country with high economic growth rates wishes to strengthen it against foreign or domestic threats by increased military spending. In contrast, it is equally plausible that countries with high economic growth divert economic resources from defense into other productive sectors such as education and health sectors (Kollias, 1997). It is also possible that military spending increase less than proportionally at low levels of GDP, then greater than economic growth at middle levels of per capita income, and, finally, less than proportionally again at very high levels of growth. This would yield a nonlinear response to economic growth and even an appearance of a negative relationship between the two variables for certain countries over various time periods.

Corresponding Author:-Masoud Ali Khalid.

Address:-College of Financial \& Administration-Department of Accounting \& IT, Cihan University/

Sulaiymani, Kurdistan Region Government/Iraq. 
With the end of the Cold War, global military spending has been reducing and it is predicted that this reduction in military spending will lead to peace dividends for less developed nations. But many less developed countries still spend a large amount of scarce resources on defence sector. For instance, $12.18 \%$ of central government expenditures are spent on military sector in lower and middle income nations in 2008 (World Development Indicator, 2011). A lacking of investment and expenditures in health, education and other social-economic activities, many LDCs' economic growth will be impacted by high military spending. For these reasons, the relationship between military spending and economic growth in less developed countries needs to be explored and analyzed carefully.

The purpose of this paper aims to investigate the military-growth nexus for 54 less developed countries in Africa, Latin America and South Asia over the period of 2005-2010. And, different panel data techniques including System GMM is used to estimate the results.

This article is organized as follows: Section 2 provides a brief literature review of the defence-growth nexus studies. Sections 3 and 4 give data and empirical results. Section 5 presents some conclusions.

\section{Literature Review:-}

The literature on military spending and economic growth dated back to the seminal work by Benoit (1973) in which a positive relationship was found. Benoit's work inaugurated a vast array of studies in the hope of identifying a definitive pattern between the two variables (e.g. Fredericksen and Weede, 1986; Stewart, 1991; Ward et al., 1991; Mueller and Atesoglu, 1993; Murdoch et al., 1997; Yildirim et al., 2005) generally appeal to Keynesian economic theory to clarify their results. Included amongst the possible economic benefits of increased military spending are enhanced infrastructure, increased aggregate demand, heightened production, lower unemployment and a more skilled workforce (Chletsos and Kollias, 1995; MacNair et al., 1995).

Conversely, other studies conclude that heightened military spending exerts a negative relationship with economic growth due to a tendency to crowd out investment and the wider impacts of tax increases that are often necessary to finance the new expenditure (Smith, 1980; Cappelen et al., 1984; Dunne et al., 2001). Furthermore, other studies found that the relationship between military expenditure and economic growth might be mixed, such as (Chowdhury, 1991; Madden and Haslehurst, 1995; Lai et al., 2002; Wilkins, 2004) or non-existent relationship such as (Grobar and Porter, 1989; Alexander, 1990; Huang and Mintz, 1990; Adams et al., 1991; Ram, 1995).

Moreover, even where defense expenditure exerts a positive relationship with economic growth, it may nonetheless prove to a sub-optimal means of economic stimulation due to the greater effect exerted by non-military expenditure (Batchelor et al., 2000; Shieh et al., 2002). Both negative and positive relationship maybe mediated by a range of region and country specific factors that not only significantly complicate investigation into the relationship between military spending and economic growth, but also render any broad conclusions elusive. For instance, where increases in military spending occur during a time of war, additional variables such as the length and severity of the conflict and the degree to which economic agents are able to predict these factors and alter their behavior accordingly will also affect these relationship (Schneider and Troger 2003).

\section{Methodology And Data:- \\ The Data:-}

In order to examine the military-growth relationship in the 54 developing countries over the period 2005-2010 and a balanced panel of time series data was constructed. The data set is balanced and the same time periods are available for all cross section units. The data are taken from the SIPRI Yearbooks for military expenditure (Stockholm International Peace Research Institute, various years) and the data on GDP and population are drawn from the World Development Indicator (WDI).

Table I:- variables descriptions: Annual data: (2005-2010; N=54)

\begin{tabular}{|l|l|l|}
\hline Variable & Description & Source \\
\hline ME & Military expenditure & SIPRI (2010) \\
\hline RGDPC & Real Gross domestic product per Capita & WDI (2010) \\
\hline POP & Population & WDI (2010) \\
\hline $\begin{array}{l}\text { Algeria, Benin, Bolivia, Botswana, Burkina Faso, Cambodia, Cameroon, Central African, Chad, Chile, China, } \\
\text { Colombia, Congo, Cuba, Dominican, Ecuador, El Salvador, Fiji, Gabon, Gambia, Guatemala, India, Indonesia, Iran, }\end{array}$ \\
\hline
\end{tabular}


Jordan, Madagascar, Malawi, Malaysia, Mali, Malta, Morocco, Mozambique, Nepal, Niger, Nigeria, Pakistan, Panama, Papua Guinea, Paraguay, Peru, Rwanda, Saudi Arabia, Senegal, Sierra Leone, South Africa, Sri Lanka, Sudan, Syria, Thailand, Togo, Tunisia, Uganda, Uruguay, Zambia.

\section{Econometric Methodology:-}

The empirical specification of this study is aimed at explaining the military-growth correlation in the less developed nations. Thus, the empirical model employed in the analysis is as follows:

$$
\begin{aligned}
& \mathrm{ME}_{\mathrm{it}}=\alpha_{1}+\alpha_{2} \mathrm{ME}_{\mathrm{it}-1}+\alpha_{3} R G D P C_{\mathrm{it}-1}+\alpha_{4} \mathrm{POP}_{\mathrm{it}-1}+\lambda_{\mathrm{i}}+\varepsilon_{\mathrm{it}}, \quad \mathrm{i}=1, \ldots \mathrm{N} ; \mathrm{t} \\
& =1, \ldots \mathrm{T}
\end{aligned}
$$

Equivalently, Eq. (1) may be written as follows:

$$
\begin{aligned}
& \mathrm{ME}_{\mathrm{it}-1}=\alpha_{1}+\alpha_{2} \mathrm{ME}_{\mathrm{it}-2}+\alpha_{3} R G D P C_{\mathrm{it}-1}+\alpha_{4} \mathrm{POP}_{\mathrm{it}-1}+\lambda_{\mathrm{i}}+\varepsilon_{\mathrm{it}-1}, \\
& =1, \ldots \mathrm{T}
\end{aligned}
$$

$\mathrm{i}=1, \ldots \mathrm{N} ; \mathrm{t}$

Where MEis military expenditure, $R G D P C$ is real gross domestic product (GDP) per capita, $P O P$ is population, and the subscripts $i$ and $t$ index countries and time, respectively. In addition, the specification also contains an unobservable country-specific effect $\mu$ and error-term $\varepsilon$.

Moreover, in this paper we employ Generalized Method of Moments (GMM) which is a semi-parametrically efficient estimation model and since Hansen (1982) has established its large sample properties, GMM has gained abundant deal of attention in the field of economics. The GMM methodology begins from a set of over-identified population of moment conditions and seeks to find an estimator that minimizes a quadratic norm of the sample moment vector.

The resulting estimation has been shown to be consistent and asymptotically normal under many circumstances. However, the GMM first difference estimator suffers from a significant weakness. Blundell and Bond (1998) found that when the independent variable is persistent over time, lagged levels of these variables are weak instruments for the regression equation expressed in first differences. Blundell and Bond (1998) also found that the instrument variable used with the first-difference GMM method (i.e. the endogenous variables lagged two or more periods) become less informative in models where the variance of the fixed effects is mainly relative to the variance of the transitory shocks. This is likely to lead to biased coefficients, and the issue is generally intensified in small samples size. To avoid this bias, Blundell and Bond (1998) suggested a system GMM (SGMM) estimator.

This method essentially combines in a system the first-differenced with the same equation expressed in levels. The instruments for the regression in differences are the same as those labeled above, while the instruments for the equation in levels are lagged differences of the corresponding variables. The main advantage of the SGMM method comprises in the fact that unlike (between or within - first differences) approaches, it does use the estimation in levels for estimation and this exploits not only the variation in data but also between the countries as well. It therefore allows preserving more information to identify the parameters of interest. Arellano and Bond (1991) display on the basis of Monte-Carlo simulation that this additional information results in a considerable gain in the precision of the estimates.

\section{The Empirical Result:-}

Our sample countries include 54 less developed nations for which data are available for over period 2005-2010. We report first estimates of Eq. (3) for the whole sample period with the standard panel data estimates, cross section estimates, random effects models REM, between and within the fixed effects models. Moreover, we shall use the systems GMM approach (SGMM) of Blundell and Bond (1998) in which the specifications in the first-step GMM, second-step GMM with robust SE of the variables are estimated simultaneously. Estimates with these alternative methods are illustrated in Table II. Two sets of subsample estimates with REM and SGMM are reported in Table III and Table IV.

In order to specify whether a fixed and random effects model are appropriate for our study weperformed the Hausman test which is distributed as $\mathrm{x}^{2}$, where the degrees of freedom are equal to the number of regressors. The results illustrate that the fixed effects model is rejected, and thisfinding is consistent with Murdoch et al. (1997) 
since random effect models areconsidered more appropriate than fixed effect models. Thus, the fixed effects model is not necessary in our case.Parameter estimates from the random effect and fixed effect are presented inTable II and Table III for the 54 less developed countries. The results obtained, similar to Smith andDunne (2001); who positive and significant correlation economic growth and military.

Furthermore, we have employed System GMM analysis based on balanced data-set, to examinethe military-growth relationship in the context of differentpolitical and welfare less developed nations. We have used an AR (1) and an AR (2) model to capture thepersistence in our sample data. Moreover, AR (1) and AR (2) models are desirable based on theArellano and Bond (1991) test for AR (2).

The system GMM estimation results of this study, presented in Table IV, and it indicates that there is a positive relationship between military expenditure, economic growth and population for the rest of the sample countries, and it's statistically significant, it means that, when economic growth, it encourages military sector to spend more on it, and also population is directly related to economic growth, meaning that when population increase, it rises military expenditure in the developing countries . All diagnosticsfor the models in each table is satisfactory. Generally, GDP and population arepositively related withmilitary spending in this study, and all variables are statisticallysignificant at different level such as the 1\%,5\% and $10 \%$ level. Theresults illustrate that as economic growth (GDP) and population are increase military expenditures as a percentage of governmentexpenditures are increased as well. Furthermore, this finding suggests that military spending plays a significant role in the less developed nations despite of many problems such as civil war, conflicts and border tensions, and this result supported by earlier works done by Benoit (1973\&1978) for 44 developing nations. Moreover, our findings are also confirmed and supported by Ali's (2007) findings in the developing countries. Moreover, these net positive relationships support the belief that military spending and economic growth are related through an expansion of aggregate demand in less developed countries. Moreover, investment in infrastructure and human capital development in LDC economies operating below full employment thus, it has positive Benoit-type spillover impacts from military expenditures. There is less evidence to suggest that military spending in developing nations negatively related to economic growth. The positive impacts that arise when relationship runs from economic growth to military spending imply that many LDCs are still at a stage where military expenditures are constrained by low income and will grow along with the economy. They are not yet in a position to have defense expenditures grow less than proportionally with economic growth.

Table II:- Random Effects Results: Dependent variable is ME.

\begin{tabular}{|l|l|l|}
\hline Variable & Coefficient & T ratio \\
\hline Constant & -14.85266 & $0.000^{*}$ \\
\hline Ln RGDPC & .8828427 & $0.000^{*}$ \\
\hline Ln POP & 1.283371 & $0.000^{*}$ \\
\hline Hausman test & 0.1139 & - \\
\hline $\mathrm{N}$ & 324 & \\
\hline Countries & 54 & \\
\hline Min obs & 6 & \\
\hline Max obs & 6 & \\
\hline Av obs & 6.0 & \\
\hline Rsq within & 0.6318 & \\
\hline Rsq between & 0.8126 & \\
\hline Rsq overall & 0.8097 & \\
\hline \multirow{*}{********}{ denote significance at $10 \%, 5 \%$ and $1 \%$, respectively. Values in parentheses are heteroscedaticity consistent } \\
$t$-statistics and values in brackets are $p$-values. \\
\hline
\end{tabular}

Table III:- Fixed Effects Results Dependent variable is ME.

\begin{tabular}{|l|l|l|}
\hline Variable & Coefficient & T ratio \\
\hline & & \\
\hline Constant & -14.85266 & $0.000^{*}$ \\
\hline Ln RGDPC & .8828427 & $0.000^{*}$ \\
\hline Ln POP & 1.283371 & $0.000^{*}$ \\
\hline Hausman test & 0.1139 & \\
\hline
\end{tabular}




\begin{tabular}{|l|l|l|}
\hline $\mathrm{N}$ & 324 & - \\
\hline Countries & 54 & - \\
\hline Min obs & 6 & \\
\hline Max obs & 6 & \\
\hline Av obs & 6.0 & \\
\hline Rsq within & 0.6318 & \\
\hline Rsq between & 0.8126 & \\
\hline Rsq overall & 0.8097 & \\
\hline \multicolumn{2}{|c|}{ denote significance at $10 \%, 5 \%$ and $1 \%$, respectively. Values in parentheses are heteroscedaticity consistent } \\
\hline \begin{tabular}{l} 
t,-statistics and values in brackets are $p$-values. \\
\hline
\end{tabular}
\end{tabular}

Table IV:- Results of system GMM estimations: Dependent variable is ME. (Sample period: 2005-2010)

\begin{tabular}{|l|l|l|l|}
\hline Variable & One-Step System GMM & Two-Step System GMM & $\begin{array}{l}\text { Two-Step System GMM with } \\
\text { Robust SE }\end{array}$ \\
\hline CONSTANT & $.6478708^{* *}$ & & -1.480849 \\
& $(0.000)$ & -1.480849 & $(0.736)$ \\
\hline LnMIXit-1 & $.783148^{* *}$ & $(0.401)$ & $.6413527^{*}$ \\
& $(0.04)$ & $.6413527^{*}$ & $(0.002)$ \\
\hline Ln RGDPCit-1 & $.1112433^{* * *}$ & $(0.000)$ & .2016423 \\
& $(0.070)$ & $.2016423^{*}$ & $(0.326)$ \\
\hline Ln POP1t & $.3607867^{*}$ & $(0.000)$ & .2861577 \\
& $(0.005)$ & $.2861577^{* *}$ & $(0.373)$ \\
\hline Sargant Test & 84.66462 & $(0.021)$ & - \\
& $(0.0000)$ & 22.37417 & -1.5967 \\
\hline AR(1) & - & $(0.0498)$ & $(0.1103)$ \\
\hline AR(2) & - & -1.8481 & .56044 \\
& & $(0.0646)$ & $(0.5752)$ \\
\hline $\mathrm{N}$ & 54 & .56618 & \\
\hline T & 6 & $(0.5713)$ & \\
\hline
\end{tabular}

Notes: All models are estimated using the Arellano and Bond dynamic panel GMM estimations (Stataxtabond command). The variables are defined as follows: ME = Military expenditure; RGDPC $=$ real GDP per capita (in US dollars; POP $=$ Population. Figures in the parentheses are t-statistics. ${ }^{(*),(* *),(* *))}$ indicate significance at $1 \%, 5 \%, 10 \%$ respectively. Time dummies were jointly significant and are not reported here to save space.

\section{Conclusion:-}

The defense-growth relationship has been an issue of keen concern in defense economics and there is a huge amount of the literature investigating the military-growth relationship in less developed nations. However, the existing literature is inconclusive as to the military-growth relationship due to applying different theoretical models, different empirical techniques and different samples. This paper examines the relationship between defense expenditure and economic growth in 54 developing countries. Our panel regressions present reasonable and robust results by applying more recent econometric techniques such as the dynamic panel System GMM estimators. The empirical panel results show that defense spending has a significant and positive relationship with economic growth in 54 sample developing countries.

Thus, the empirical estimations support the positive relationship between defense spending and economic growth, and they are consensus of Kollias (1997) and Ali (2012). Furthermore, proper regression model and more advanced econometric methodologies do improve empirical results in this article which could make contributions to the defense economics literature.

\section{References:-}

1. Adams, F.G., Behrman, J.R. and Boldin, M. (1991) Government expenditures, defense and economic growth in LDCs: a revised perspective. Conflict Management and Peace Science 11(2) 19-35. 
2. Alexander, W.R.J. (1990) The impact of defence spending on economic growth: a multi-sectoral approach to defense spending and economic growth with evidence from developed economies. Defense Economics 2(1) 3955.

3. Ali, H. E. (2007). "Military expenditures and inequality: empirical evidence from global data." Defence and Peace Economics 18(6): 519-535.

4. Ali, H. E. (2012). "Military expenditures and inequality in the middle east and north africa: A panel analysis." Defence and Peace Economics 23(6): 575-589.

5. Arellano, M. and S. Bond (1991). "Some tests of specification for panel data: Monte Carlo evidence and an application to employment equations." The review of economic studies 58(2): 277-297.

6. Batchelor, P., Dunne, P. and Saal, D. (2000) Military spending and economic growth in South Africa. Defence and Peace Economics 11(6) 553-571.

7. Benoit, E. (1973). "Defense and economic growth in developing countries."

8. Benoit, E. (1978). "Growth and defense in developing countries." Economic Development and Cultural Change: 271-280.

9. Blundell, R. and S. Bond (1998). "Initial conditions and moment restrictions in dynamic panel data models." Journal of econometrics 87(1): 115-143.

10. Cappelen, A., Gleditsch, N.P. and Bjerkholt, O. (1984) Military spending and economic growth in the OECD countries. Journal of Peace Research 21(4) 361-373.

11. Chletsos, M. and Kollias, C. (1995) The demand for Turkish military expenditure 1960-1992. Cyprus Journal of Economics 8(1) 64-74.

12. Chowdhury, A.R. (1991) A causal analysis of defense spending and economic growth. The Journal of Conflict Resolution 35(1) 80-97.

13. Deger, S. (1986). Economic development and defense expenditure. Economic Development and Cultural Change, 35 (1), 179- 196.

14. Dunne, P., Nikolaidoua, E. and Vougas, D. (2001) Defence spending and economic growth: a causal analysis for Greece and Turkey. Defence and Peace Economics 12(1) 5-26.

15. Joerding,W. (1986). Economic growth and defense spending. Journal of Development Economics, $21,35-40$.

16. Huang, C. and Mintz, A. (1990) Ridge regression analysis of the defense-growth tradeoff in the United States. Defense Economics 2(1) 19-37.

17. Hansen, L. P. (1982). "Large sample properties of generalized method of moments estimators." Econometrica: Journal of the Econometric Society: 1029-1054.

18. Grobar, L.M. and Porter, R.C. (1989) Defense spending and economic growth in LDCs. Journal of Conflict Resolution 33(2) 318-345.

19. Kollias, C., et al. (1997). "Defence expenditure and economic growth in the European Union: a causality analysis." Journal of Policy Modeling 26(5): 553-569.

20. Lai, C.C., Shieh, J.Y. and Chang, W.Y. (2002) Endogenous growth and defense expenditures: a new explanation of the Benoit hypothesis. Defence and Peace Economics 13(3) 179-186.

21. MacNair, E., Murdoch, C. and Sandler, T. (1995) Growth and defense: pooled estimates for the NATO alliance, 1951-1988. Southern Economic Journal 61 846-860.

22. Madden, G. and Haslehurst, P. (1995) Causal analysis of Australian economic growth and military expenditure: a note. Defence and Peace Economics 6(2) 115-121.

23. Mueller, M.J. and Atesoglu, H.S. (1993) Defense spending, technological change and economic growth in the United States. Defence Economics 4(3) 259-269.

24. Murdoch, J.C., Pi, C.-R. and Sandler, T. (1997) The impact of defense and nondefense public spending on growth in Asia and Latin America. Defence and Peace Economics 8(2) 205-224.

25. Ram, R. (1995). Defense expenditure and economic growth. In Handbook of Defense Economics, Vol 1, edited by K. Hartley and T. Sandler. London: Elsevier, 251-273.

26. Shieh, J., Lai, C. and Chang, W. (2002) The impact of military burden on longrun growth and welfare. Journal of Development Economics 68 443-455.

27. Schneider, G. and Troger, V.E. (2003). War and the World Economy: Stock Market Reactions to International Conflicts, 1990-2000. Paper presented at the ISA Annual Meeting. http://www.unikonstanz.de/FuF/Verwiss/GSchneider/downloads/papers/Schneider-Tr\%F6ger.pdf (Accessed $14 \quad$ February 2009)

28. Smith, R. (1980) Military expenditure and investment in OECD 1954-1973. Journal of Comparative Economics 4(1) 19-32. 
29. Smith, R. and P. Dunne (2001). "Military expenditure growth and investment." Birbeck College and Middlesex University Business School, Abril.

30. Stewart, D.B. (1991) Economic growth and the defence burden in Africa and Latin America: simulations from a dynamic model. Economic Development and Cultural Change 40(1) 189-207.

31. Stockholm International Peace Research Institute (SIPRI 2010), http://www.sipri.org/. World Armaments and Disarmaments. Oxford: Oxford University Press.

32. Ward, M.D., Davis, D., Penubarti, M., Rajmaira, S. and Cochran, M. (1991) Military spending in India: Country Survey 1. Defence Economics 3(1) 41-63.

33. Weede, E. (1986) Rent seeking, military participation and economic performance in LDCs. Journal of Conflict Resolution 30(2) 77-91.

34. Wilkins, N. (2004). Defence expenditure and economic growth: evidence from a panel of 85 countries. http:// cama.anu.edu.au/macroworkshop/Nigel\%20Wilkins.pdf (accessed 14 August 2008).

35. World Development Indicator- World Bank. (2010).http://data.worldbank.org/topic

36. Yildirim, J., Sezgin, S. and Öcal, N. (2005) Military expenditure and economic growth in Middle Eastern countries: a dynamic panel data analysis. Defence and Peace Economics 16(4) 283-295. 